\title{
De strijd van de burgemeester tegen drugscriminaliteit
}

\section{Een eerste statistische analyse van de toepassing van artikel $13 \mathrm{~b}$ Opiumwet}

Mr. dr. Michel Vols en Michelle Bruijn LLB

\author{
Aanbevolen citeerwijze bij dit artikel \\ Mr. dr. Michel Vols en Michelle Bruijn LLB, 'De strijd van de burgemeester tegen \\ drugscriminaliteit', NALL oktober 2015, DOI: 10.5553/NALL/.000021
}

\section{Inleiding}

Drugshandel en hennepteelt in en vanuit woningen hebben een negatieve invloed op de leefbaarheid in wijken. ${ }^{\mathbf{1}}$ Het zijn tevens vormen van 'ondermijnende criminaliteit' die de rechtstaat en samenleving bedreigen. ${ }^{2}$ De laatste decennia is de strijd tegen deze woninggerelateerde drugscriminaliteit daarom opgevoerd door de politie, het Openbaar Ministerie, lokale overheden en verhuurders. ${ }^{3}$

Vanaf 1997 trachten burgemeesters drugsgerelateerde overlast veelal aan te pakken met behulp van artikel 174a Gemeentewet (de Wet Victoria). ${ }^{4}$ In de praktijk blijkt de voor toepassing vereiste verstoring van de openbare orde veelal lastig aan te tonen. Drugsdealers doen hun uiterste best om geen overlast te veroorzaken en intimideren omwonenden zodat deze niet durven te klagen. ${ }^{\mathbf{5}}$ In 2007 verleent de wetgever de burgemeester daarom een nieuwe bevoegdheid om drugscriminaliteit in woningen aan te pakken. De bevoegdheid in artikel 13b Opiumwet (de Wet Damocles) is sindsdien ook toepasbaar bij het tegengaan van drugshandel vanuit woningen. De burgemeester is bevoegd om bestuursdwang toe te passen indien in woningen of op het bij de woning behorende erf een middel als bedoeld in lijst I of II van de Opiumwet wordt verkocht, afgeleverd of verstrekt dan wel daartoe aanwezig is. ${ }^{6}$

In de gemeentelijke praktijk betekent de toepassing van de bevoegdheid dat de burgemeester een woning fysiek sluit: veelal worden deuren en ramen dichtgetimmerd en de woning verzegeld. De sluiting van de woning heeft doorgaans grote gevolgen voor de bewoners van de woning. Zij worden geconfronteerd met het (tijdelijke) verlies van hun woning en dus met een zeer ingrijpende inmenging in het recht op privéleven. ${ }^{7}$ Het is daarom niet verwonderlijk dat de toepassing van de bevoegdheid uit artikel 
13b Opiumwet soms tot de nodige (juridische) ophef leidt.

Recentelijk ontstond consternatie over een uitspraak van de Rechtbank Noord-Nederland. ${ }^{\mathbf{8}}$ De rechtbank acht het handhavingsbeleid van de gemeente Emmen onredelijk, omdat in het beleid staat opgenomen dat de enkele aanwezigheid van een handelshoeveelheid drugs tot sluiting van de woning leidt. Het handhavingsbeleid houdt in dat als een grote handelshoeveelheid (van twintig planten of meer) wordt geconstateerd overgegaan wordt tot sluiting van de woning zonder eerst te waarschuwen. De rechtbank oordeelt dat een eerste constatering van de enkele aanwezigheid van een handelshoeveelheid onvoldoende is om direct over te gaan tot sluiting van de woning. Om direct over te gaan tot sluiting zonder eerst een waarschuwing te geven, moet er volgens de rechtbank sprake zijn van een ernstig geval. Daarnaast beslist de rechtbank dat het beleid geen ruimte laat om rekening te houden met de omstandigheden van het specifieke geval. In hoger beroep betoogt de burgemeester dat het handhavingsbeleid ruimte geeft om in schrijnende gevallen van het beleid af te wijken en dat sluiting bedoeld is als ultimum remedium. De Afdeling is het hiermee eens en beslist dat het handhavingsbeleid voldoende ruimte biedt om met een minder vergaande maatregel dan sluiting te volstaan.

Daarmee acht de Afdeling het beleid rechtmatig en vernietigt de aangevallen uitspraak.9

Deze zaak laat zien dat niet alleen onder burgers, maar ook in de praktijk onduidelijkheid bestaat over wat rechtmatig is in het kader van woningsluiting bij het aantreffen van een handelshoeveelheid drugs. Er is bovendien behoefte aan betrouwbare cijfers over de toepassing van artikel 13b Opiumwet. ${ }^{10} \mathrm{Om}$ in deze behoeften te voorzien, hebben wij een analyse gemaakt van de toepassing van artikel 13b Opiumwet. Onderdeel van deze analyse is een statistische analyse van gepubliceerde jurisprudentie over die toepassing.

In dit artikel staan drie vragen centraal: (1) Hoe vaak wordt artikel 13b Opiumwet toegepast en welke gedragingen leiden tot het gebruik van de bevoegdheid? (2) Hoe vaak leidt de sluiting van een woning tot een voorlopigevoorzieningenprocedure of beroepsprocedure bij de rechter en wat zijn de kenmerken van deze zaken? (3) Onder welke omstandigheden vecht de belanghebbende het sluitingsbesluit met succes aan bij de (voorzieningen)rechter?

Om deze vragen te beantwoorden wordt allereerst de omvang van de toepassing van de Wet Damocles in gemeenten onderzocht (par. 2). Daarna wordt jurisprudentie over de toepassing van artikel 13b Opiumwet systematisch in kaart gebracht en statistisch geanalyseerd: in paragraaf 3 worden de methoden van dit kwantitatieve onderzoek toegelicht, waarna in paragraaf 4 de resultaten van de analyse worden gepresenteerd. Ten slotte worden de resultaten kritisch besproken en worden conclusies getrokken (par. 5).

\section{Toepassing in de gemeenten}

Het is onbekend hoe vaak artikel $13 \mathrm{~b}$ Opiumwet is toegepast tussen november 2007 en januari 2015. Er zijn wel enkele onderzoeken die enigszins een beeld geven van de toepassing. In 2008 ondervroegen Vols \& De Jonge veertig gemeenten over de toepassing van artikel 13b Opiumwet 
bij woningen. Uit deze inventarisatie blijkt dat 32 gemeenten aangeven nog niet aan de toepassing van de bevoegdheid te zijn toegekomen. In acht gemeenten heeft de burgemeester al wel van de bevoegdheid gebruik gemaakt. In vier van die gemeenten waren één tot drie woningen gesloten, in één gemeente vier of vijf woningen, in twee gemeenten zes tot tien woningen en in één gemeente meer dan tien woningen. ${ }^{\mathbf{1 1}}$ In 2010 benaderen Holtslag \& Vols dezelfde veertig gemeenten. Achttien respondenten geven aan artikel 13b Opiumwet in te zetten bij woningen. Meerdere respondenten melden 'goede ervaringen' te hebben met de toepassing van artikel $13 \mathrm{~b}$ Opiumwet bij woningen. ${ }^{12}$

Er lijkt op basis van bovenstaande onderzoeken tussen 2008 en 2010 een toename te zijn geweest in de toepassing van artikel $13 \mathrm{~b}$ Opiumwet. Het is onbekend of dit zich na 2010 heeft voortgezet en hoeveel woningen per jaar worden gesloten op grond van de Wet Damocles. Er is na 2010 geen kwantitatief onderzoek meer verricht naar de toepassing van de bepaling. We hebben daarom voor dit onderzoek een inventarisatie gemaakt van gepubliceerde beleidsstukken van politie, gemeenten en andere overheidsinstanties om een globaal beeld te krijgen van de omvang van de woninggerelateerde drugscriminaliteit en de toepassing van artikel 13b Opiumwet.

Uit onderzoek van het Wetenschappelijk Onderzoek- en Documentatiecentrum (WODC) van het ministerie van Veiligheid en Justitie blijkt dat de politie in 2012 ruim 19.000 drugsfeiten heeft geregistreerd. In bijna 30\% van deze feiten gaat het om gevonden hennepplantages, in $11 \%$ gaat het om handel in harddrugs, in $6 \%$ om handel in softdrugs en in minder dan $1 \%$ om het vervaardigen van harddrugs. ${ }^{13}$ De handel in harddrugs en softdrugs betreft echter zowel handel in panden als handel op straat, dus de precieze omvang van de woninggerelateerde drugscriminaliteit blijkt onbekend. Het onderzoek laat wel zien dat een groot deel van feiten wordt gepleegd vanuit een woning of 'drugspand'. Uit een analyse van 638 dossiers over drugsfeiten blijkt dat in bijna 80\% van de hennepteeltzaken sprake is van teelt in een woning. ${ }^{\mathbf{1 4}}$ In ongeveer 30\% van de zaken over handel in harddrugs zijn de drugs vanuit een drugspand verhandeld en in ruim $10 \%$ van de zaken over softdrugshandel is sprake van handel vanuit een drugspand. ${ }^{\mathbf{1 5}}$ In de zaken over het vervaardigen van harddrugs is de productielocatie in iets meer dan de helft van de gevallen een woning. ${ }^{\mathbf{6}}$

Het onderzoek van het WODC laat daarnaast zien dat de meeste drugsfeiten worden geregistreerd in de provincie Limburg. Deze provincie kent 23,7 geregistreerde drugsfeiten per 10.000 inwoners en scoort op zowel bezit, handel als vervaardigen van hard- en softdrugs hoger dan het landelijk gemiddelde. Noord-Brabant scoort eveneens hoog met zestien geregistreerde drugsfeiten per 10.000 inwoners. Het aantal geregistreerde feiten rond hennepplantages ligt in deze provincie op een hoger niveau dan gemiddeld. ${ }^{17}$ Dat de woninggerelateerde drugscriminaliteit het grootste lijkt te zijn in Limburg en Noord-Brabant bleek ook al in onderzoek van Vols \& De Jonge. Zij constateren in 2009 dat vooral burgemeesters van 'grensgemeenten, die in hoge mate te maken hebben met overlast door drugshandel' de bevoegdheid van artikel 13 b Opiumwet toepassen. ${ }^{18}$ Deze trend lijkt zich nadien voort te zetten: vooral burgemeesters van Limburgse gemeenten lijken de bevoegdheid uit artikel 13b Opiumwet te gebruiken. 
Uit het jaarverslag 2012 van het Regionale Informatie en Expertise Centrum (RIEC) Limburg blijkt dat de burgemeesters in dat jaar 135 keer een pand (lokalen en woningen) sloten op de grond van artikel 13b Opiumwet. In 377 gevallen werd een waarschuwing voor de toepassing van artikel 13b Opiumwet gegeven. ${ }^{19}$

In het gezamenlijke jaarverslag 2013 van de Regionale Informatie en Expertise Centra valt wederom op dat artikel 13b Opiumwet vooral in de provincie Limburg wordt ingezet: in 2013 wordt in 86 casussen een waarschuwing gegeven en 73 panden (dus woningen en lokalen) op basis van artikel 13b Opiumwet gesloten. ${ }^{\mathbf{2 0}}$ Uit dit document valt af te leiden dat de bevoegdheid ook in andere provincies wordt toegepast, maar in mindere mate: Noord-Holland (vijftien waarschuwingen, vijf sluitingen), Den Haag (één waarschuwing, vier sluitingen), Midden-Nederland (twee sluitingen), Amsterdam-Amstelland (één sluiting) en Rotterdam (één waarschuwing). ${ }^{21}$

Het RIEC blijkt echter niet alle sluitingen te registreren. Zo sluit de burgemeester van Rotterdam in 2013 tien panden en geeft hij dertig waarschuwingen voor de toepassing van artikel $13 \mathrm{~b}$ Opiumwet. ${ }^{22}$ In andere jaren past de Rotterdamse burgemeester de bevoegdheid ook toe. De gemeente Rotterdam constateert een 'stijgende lijn' in het aantal dossiers en maatregelen: in 2011 zijn er zeven sluitingen en veertien waarschuwingen en in 2012 negen sluitingen en 23 waarschuwingen. De belangrijkste redenen van de toename zouden de nauwe samenwerking tussen de gemeentelijke instanties en de toenemende bekendheid van artikel 13b Opiumwet zijn. ${ }^{\mathbf{2 3}}$ De toepassing van de bevoegdheid neemt ook in Tilburg toe: in 2012 geeft de burgemeester negentien waarschuwingen en sluit hij zes woningen. In 2013 gaat het om tien waarschuwingen en zestien sluitingen en in 2014 om vijf waarschuwingen en 27 sluitingen. ${ }^{\mathbf{2 4}}$ In Groningen is eveneens een stijgende lijn te zien. In 2013 meldt de burgemeester negen panden te hebben gesloten. In 2014 waarschuwt de burgemeester drie keer voor sluiting en sluit hij veertien keer. Er volgen vijf bezwaarprocedures en twee verzoeken op een voorlopige voorziening. De toename van het aantal gesloten panden is volgens de burgemeester van Groningen het gevolg van verbeterde samenwerking tussen gemeente en politie en extra personele ondersteuning binnen de gemeentelijke organisatie. ${ }^{25}$

Aan de hand van de bovenstaande analyse constateren wij voorzichtig dat er een stijgende lijn zit in het aantal sluitingen van woningen naar aanleiding van drugscriminaliteit. In de gepubliceerde cijfers wordt veelal geen onderscheid gemaakt tussen het sluiten van een voor het publiek toegankelijk lokaal en een woning. Hierdoor zijn geen precieze cijfers bekend over het aantal woningen dat wordt gesloten op grond van artikel 13b Opiumwet. Uit de cijfers van de onderzoeksrapporten valt op wel te maken dat artikel 13b Opiumwet de laatste jaren zeker honderd maar waarschijnlijk niet meer dan vierhonderd keer is toegepast in het geval van drugshandel in/rondom woningen. Uit de onderzoeken blijkt eveneens dat de meeste (woninggerelateerde) drugscriminaliteit wordt geregistreerd in de provincie Limburg. Tevens blijkt Limburg in zowel 2009 als 2013 de provincie te zijn waarin de bevoegdheid uit artikel 13b Opiumwet het vaakst wordt toegepast. In andere provincies wordt de bevoegdheid in mindere mate toegepast, maar valt eveneens een stijgende lijn te 
constateren. Artikel 13b Opiumwet lijkt bovendien veelvuldig te worden gebruikt voor het geven van een waarschuwing voor sluiting.

\section{Methoden kwantitatieve analyse jurisprudentie}

In dit artikel analyseren wij gepubliceerde jurisprudentie van rechtbanken over de toepassing van artikel $13 \mathrm{~b}$ Opiumwet bij woningen. Deze gerechtelijke procedures zijn tot op heden onvoldoende onderzocht en er zijn tot dusver geen statistische gegevens verzameld.

Wij hebben alle gepubliceerde jurisprudentie over de toepassing van artikel 13b Opiumwet bij woningen op www.rechtspraak.nl verzameld. Er is gebruik gemaakt van vaste zoektermen om herhaling van het onderzoek mogelijk te maken. Door gebruik te maken van verschillende combinaties van de zoektermen '13b Opiumwet', 'woning' en 'woningsluiting', is getracht om alle beschikbare jurisprudentie te vinden over woningsluiting op grond van artikel 13b Opiumwet. Vervolgens is handmatig gefilterd op uitspraken van de rechtbank en uitspraken over de sluiting van een woning. Hierdoor zijn zaken over lokalen, inrichtingen en schuren niet meegenomen in het onderzoek. Bovendien beperkt het onderzoek zich tot uitspraken van de rechtbanken.

In totaal zijn er 65 gepubliceerde uitspraken gevonden in de periode van november 2007 tot januari 2015. Voor november 2007 is gekozen omdat artikel 13b Opiumwet sindsdien van toepassing is op woningen. De 65 gevonden uitspraken zijn te onderscheiden in bodemprocedures (17) en voorlopigevoorzieningenprocedures (48). Vervolgens zijn deze uitspraken gelezen en gecodeerd. ${ }^{\mathbf{2 6}}$ Bij het coderen worden verschillende variabelen in een computerdatabase genoteerd, zoals de datum van de uitspraak, soort procedure, soort belanghebbende, locatie van de rechtbank, reden van woningsluiting, de verdediging van de belanghebbende en de uitspraak van de rechtbank. Ten slotte hebben wij de verkregen data tot kruistabellen omgewerkt en geanalyseerd. Wij hebben daarbij Fishers exacte toets toegepast, omdat er sprake is van een relatief kleine dataset. Dit is een statistische toets die de kans (p-waarde) berekent dat een verdeling het gevolg is van toeval. De test berekent de afwijking van de nulhypothese die aanneemt dat er geen relatie tussen variabelen (bijv. de soort drugs en de rechterlijke uitspraak) bestaat. Alle p-waarden in dit artikel zijn gebaseerd op Fishers exacte toets. De nulhypothese wordt verworpen als de p-waarde lager is dan $0.05 .{ }^{27}$

\section{Onderzoeksresultaten}

In deze paragraaf analyseren wij 65 uitspraken over de toepassing van artikel 13b Opiumwet ten aanzien van woningen. Deze uitspraken zijn door verschillende rechtbanken gedaan. ${ }^{\mathbf{2 8}}$ Het totale aantal zaken verdeeld over de provincies is als volgt: Overijssel 1, Friesland 1, Drenthe 3, Utrecht 4, Zuid-Holland 6, Noord-Brabant 7, Noord-Holland 12 en Limburg 31. In alle 65 geanalyseerde zaken heeft de burgemeester op grond van artikel 13b Opiumwet besloten om de woning te sluiten. In slechts één zaak is voorafgaand aan de sluiting een waarschuwing gegeven.

In 48 (73.8\%) zaken blijkt uit de uitspraak dat de desbetreffende burgemeester beleidsregels heeft opgesteld over het sluiten van woningen, 
de aanpak van drugshandel en/of de toepassing van artikel 13b Opiumwet. Uit de geanalyseerde uitspraken blijkt dat de duur van de sluiting varieert tussen de drie en de twaalf maanden. Het is slechts één keer voorgekomen dat een woning voor één maand werd gesloten. In 22 zaken is de woning gesloten voor een periode van drie maanden, in 22 zaken is de woning gesloten voor zes maanden en in twintig zaken is de woning gesloten voor de duur van twaalf maanden.

Tabel 1 laat zien dat de belanghebbende in 29 zaken (44.6\%) de sluiting van de woning succesvol aanvecht: de voorlopige voorziening wordt toegewezen of het beroep wordt gegrond verklaard.

Tabel 1 Soort procedure en uitspraak

\begin{tabular}{|l|l|l|l|}
\hline $\begin{array}{l}\text { Soort } \\
\text { procedure }\end{array}$ & $\begin{array}{l}\text { Belanghebbende } \\
\text { krijgt gelijk }\end{array}$ & $\begin{array}{l}\text { Belanghebbende } \\
\text { krijgt geen gelijk }\end{array}$ & Totaal \\
\hline $\begin{array}{l}\text { Voorlopige } \\
\text { voorziening }\end{array}$ & 20 & 28 & $\mathbf{4 8}$ \\
\hline Beroep & 9 & 8 & $\mathbf{1 7}$ \\
\hline Totaal & $\mathbf{2 9}$ & $\mathbf{3 6}$ & $\mathbf{6 5}$ \\
\hline
\end{tabular}

Van de 65 zaken betreft het 48 voorlopigevoorzieningenprocedures en zeventien beroepsprocedures. In twintig voorlopige voorzieningenprocedures (41.7\%) kreeg de belanghebbende gelijk. In een beroepsprocedure was dit het geval in negen zaken (45.0\%). ${ }^{29}$ Hoewel het aantal keren succes voor de belanghebbende dus iets groter is bij een beroepsprocedure, betreft het geen significant verschil $(p=0.3)$.

\subsection{Soort belanghebbenden}

Tabel 2 laat zien dat in 55 zaken (84.6\%) de belanghebbende de bewoner van de woning is. In veertig zaken (61.5\%) is de belanghebbende de eigenaar van de woning. In de meerderheid van de veertig zaken waarin de belanghebbende eigenaar was, blijkt de eigenaar de woning ook te bewonen. In 25 zaken (38.5\%) was de belanghebbende bewoner maar geen eigenaar van de woning. Het gaat dan doorgaans om huurders. In tien zaken bewoonde de eigenaar de woning niet, maar verhuurde hij deze veelal.

Tabel 2 Soort belanghebbende

\begin{tabular}{|l|l|l|l|}
\hline $\begin{array}{l}\text { Soort } \\
\text { belanghebbende }\end{array}$ & $\begin{array}{l}\text { Belanghebbende } \\
\text { krijgt gelijk }\end{array}$ & $\begin{array}{l}\text { Belanghebbende } \\
\text { krijgt geen gelijk }\end{array}$ & Totaal \\
\hline $\begin{array}{l}\text { Bewoner en } \\
\text { eigenaar }\end{array}$ & 14 & 16 & $\mathbf{3 0}$ \\
\hline Alleen bewoner & 12 & 13 & $\mathbf{2 5}$ \\
\hline Alleen eigenaar & 3 & 7 & $\mathbf{1 0}$ \\
\hline & & & \\
\hline
\end{tabular}


In de 55 zaken waarin de belanghebbende bewoner is, krijgt de belanghebbende 26 keer gelijk (47.3\%). In de tien zaken waarin de belanghebbende de woning niet bewoont, krijgt hij drie keer gelijk (30.0\%). Dit betreft echter geen significant verschil ( $\mathrm{p}=0.25)$. In twaalf van de 25 zaken (48.0\%) waarin de belanghebbende slechts de bewoner van de woning is, vecht de belanghebbende de sluiting met succes aan. Dat is ook het geval in zeventien van de veertig zaken (42.5\%) waarin de belanghebbende de eigenaar is. Dit is eveneens geen significant verschil $(\mathrm{p}=0.42)$.

\subsection{Grondslag voor sluiting}

Tabel 3 laat zien dat verschillende redenen voor de sluiting worden opgeworpen door de burgemeester. In twee zaken blijkt niet uit de uitspraak waarom de woning is gesloten.

Tabel 3 Reden voor sluiting

\begin{tabular}{|l|l|l|l|}
\hline $\begin{array}{l}\text { Reden voor } \\
\text { sluiting }\end{array}$ & $\begin{array}{l}\text { Reden is } \\
\text { een } \\
\text { grondslag }\end{array}$ & $\begin{array}{l}\text { Reden is } \\
\text { enige } \\
\text { grondslag }\end{array}$ & $\begin{array}{l}\text { Totaal aantal } \\
\text { keren } \\
\text { opgeworpen }\end{array}$ \\
\hline Handelshoeveelheid & 17 & 30 & 47 \\
\hline Hennepteelt & 11 & 13 & $\mathbf{2 4}$ \\
\hline Actieve drugshandel & 6 & 3 & $\mathbf{9}$ \\
\hline Laboratorium & 1 & 0 & $\mathbf{1}$ \\
\hline Onbekend & - & - & $\mathbf{2}$ \\
\hline
\end{tabular}

Er zijn vier belangrijke redenen voor de sluiting. Ten eerste sluiten burgemeesters woningen vanwege de aanwezigheid van een handelshoeveelheid drugs. Van een handelshoeveelheid is sprake als uit de aangetroffen hoeveelheid verdovende middelen kan worden afgeleid dat er geen sprake is van een hoeveelheid die bestemd is voor eigen gebruik. ${ }^{\mathbf{3 0}}$ In 47 zaken (72.3\%) noemt de burgemeester een handelshoeveelheid als een reden voor het sluiten van de woning. In dertig zaken (46.2\%) is het hebben van een handelshoeveelheid drugs zelfs de enige grondslag voor het sluiten van de woning.

Ten tweede vormt hennepteelt in de woning een belangrijke reden voor burgemeesters om een woning te sluiten. Bij hennepteelt gaat het doorgaans om de aanwezigheid van een (handels)hoeveelheid hennepplanten in de woning, veelal in combinatie met verpakkingsmaterialen, droogrekken en weegschalen. In sommige gevallen is ook een hennepdrogerij en/of een -knipperij in de woning aangetroffen. In 24 zaken (36.9\%) wordt hennepteelt als een reden genoemd. In dertien zaken (20.0\%) vormt hennepteelt de enige grondslag voor de sluiting. Ten derde noemen burgemeesters actieve drugshandel als grondslag voor 
de sluiting. In deze zaken betoogt de burgemeester dat drugsdealers vanuit of rondom de woning actief in verdovende middelen handelen. In negen zaken (13.8\%) vormt actieve drugshandel een reden voor woningsluiting en in slechts drie zaken (4.6\%) is dit de enige reden. Ten slotte sluit de burgemeester in één zaak de woning wegens de aanwezigheid van een laboratorium in de woning. In de woning worden dan chemicaliën, verwarmingselementen en filters aangetroffen. Het ging in dat geval om grootschalige productieprocessen.

De burgemeester kan op grond van artikel 13b Opiumwet een woning sluiten wegens de handel in zowel harddrugs als softdrugs. In de meerderheid van de zaken is het mogelijk om te achterhalen welke soort drugs tot de sluiting van de woning heeft geleid. Uit tabel 4 blijkt dat dit in zes zaken (9.2\%) niet mogelijk was. In drie zaken zijn geen drugs aangetroffen in de woning, maar zijn slechts resten van hennepplanten of een niet in werking zijnde hennepkwekerij aangetroffen. In al deze zaken kreeg de belanghebbende gelijk van de rechter. In 36 zaken (55.4\%) heeft de handel en/of aanwezigheid van 'alleen' softdrugs geleid tot de sluiting van de woning. In veertien zaken (21.5\%) werd 'slechts' geconstateerd dat gehandeld werd in harddrugs en/of een handelshoeveelheid harddrugs in de woning aanwezig was. In zes zaken (9.2\%) worden zowel hard- als softdrugs verhandeld en/of een handelshoeveelheid van beide soorten drugs aangetroffen in de woning. Dat betekent dus dat in bijna twee derde van de zaken (64.6\%) handel in en/of aanwezigheid van een handelshoeveelheid softdrugs een reden is voor de sluiting van de woning.

Tabel 4 Soort drugs aangetroffen in de woning

\begin{tabular}{|l|l|l|l|}
\hline Soort & $\begin{array}{l}\text { Belanghebbende } \\
\text { gelijk }\end{array}$ & $\begin{array}{l}\text { Belanghebbende } \\
\text { ongelijk }\end{array}$ & $\begin{array}{l}\text { Totaal } \\
\text { aantal } \\
\text { zaken }\end{array}$ \\
\hline $\begin{array}{l}\text { Alleen } \\
\text { softdrugs }\end{array}$ & 18 & 18 & $\mathbf{3 6}$ \\
\hline $\begin{array}{l}\text { Alleen } \\
\text { harddrugs }\end{array}$ & 3 & 11 & $\mathbf{1 4}$ \\
\hline $\begin{array}{l}\text { Zowel hard- } \\
\text { als softdrugs }\end{array}$ & 3 & 3 & $\mathbf{6}$ \\
\hline Geen drugs & 3 & 0 & $\mathbf{3}$ \\
\hline Onbekend & 2 & 4 & $\mathbf{6}$ \\
\hline Totaal & $\mathbf{2 9}$ & $\mathbf{3 6}$ & $\mathbf{6 5}$ \\
\hline
\end{tabular}

In drie van de veertien zaken (21.4\%) waarin alleen harddrugs een rol spelen, vecht de belanghebbende de sluiting met succes aan. In de 36 zaken waarin alleen softdrugs is aangetroffen, vecht de belanghebbende de sluiting in achttien zaken (50.0\%) met succes aan. Hoewel de kans op succes voor de belanghebbende in zaken omtrent softdrugs dus flink groter lijkt, toont een statistische analyse aan dat er (net) geen significant verschil in uitkomst is tussen de zaken over alleen harddrugs en alleen softdrugs 
$(\mathrm{p}=0.06)$.

In 25 van 42 zaken waarin softdrugs een rol spelen, kan worden vastgesteld hoeveel gram softdrugs is aangetroffen in de woning. In de overige zaken over softdrugs gaat het om hennepplantages (zie tabel 6) of wordt niet in de uitspraak benoemd hoeveel gram softdrugs is aangetroffen. ${ }^{\mathbf{3}}$ In totaal is in 25 zaken ruim 931 kilogram softdrugs aangetroffen: gemiddeld is dit per zaak iets meer dan 37 kilogram. De mediaan is negen kilogram..$^{\mathbf{2}}$ Uit tabel 5 blijkt dat in veertien van deze 25 zaken (56.0\%) de hoeveelheid softdrugs hoogstens tien kilogram is, waarbij 4.7 gram de kleinste hoeveelheid is.33 In vijf van de 25 zaken (20.0\%) is een hoeveelheid gevonden van meer dan veertig kilogram, waarbij de grootste hoeveelheid ruim 446 kilogram is.

Tabel 5 Hoeveelheid softdrugs in gram per zaak

\begin{tabular}{|l|l|l|l|}
\hline $\begin{array}{l}\text { Hoeveelheid } \\
\text { in gram }\end{array}$ & $\begin{array}{l}\text { Belanghebbende } \\
\text { gelijk }\end{array}$ & $\begin{array}{l}\text { Belanghebbende } \\
\text { ongelijk }\end{array}$ & $\begin{array}{l}\text { Totaal } \\
\text { aantal } \\
\text { zaken }\end{array}$ \\
\hline $1-10.000$ & 6 & 8 & $\mathbf{1 4}$ \\
\hline $\begin{array}{l}10.001- \\
20.000\end{array}$ & 0 & 2 & $\mathbf{2}$ \\
\hline $\begin{array}{l}20.001- \\
40.000\end{array}$ & 1 & 3 & 4 \\
\hline$>40.000$ & 4 & 1 & $\mathbf{5}$ \\
\hline Totaal & $\mathbf{1 1}$ & $\mathbf{1 4}$ & $\mathbf{2 5}$ \\
\hline
\end{tabular}

In de veertien zaken waarin hoogstens tien kilogram softdrugs is aangetroffen in de woning, vecht de belanghebbende zesmaal (42.9\%) het besluit met succes aan. In de gevallen waarin meer dan tien kilogram is aangetroffen, is dat in iets meer dan $45 \%$ van de zaken het geval. Er is dus geen sprake van een significant verschil $(\mathrm{p}=0.6)$.

Tabel 6 laat zien dat in achttien van de 42 zaken waarin softdrugs een rol spelen hennepplanten in de woning zijn aangetroffen. In totaal gaat het om 7.234 planten. Dit levert een gemiddelde van 402 planten per zaak op. De mediaan is 242,5 planten. In zeven van de achttien zaken (38.9\%) is een hoeveelheid gevonden van honderd planten of minder, waarbij 42 planten de kleinste hoeveelheid is. In acht van de achttien zaken (44.4\%) is een hoeveelheid gevonden van meer dan driehonderd planten, waarbij achttienhonderd planten de grootste aangetroffen hoeveelheid is.

Tabel 6 Hoeveelheid softdrugs in aantal planten per zaak

\begin{tabular}{|l|l|l|l|}
\hline $\begin{array}{l}\text { Aantal } \\
\text { planten }\end{array}$ & $\begin{array}{l}\text { Belanghebbende } \\
\text { gelijk }\end{array}$ & $\begin{array}{l}\text { Belanghebbende } \\
\text { ongelijk }\end{array}$ & $\begin{array}{l}\text { Totaal } \\
\text { aantal } \\
\text { zaken }\end{array}$ \\
\hline $1-100$ & 5 & 2 & 7 \\
\hline & & & \\
\hline
\end{tabular}




\begin{tabular}{|l|l|l|l|}
\hline $101-200$ & 1 & 0 & $\mathbf{1}$ \\
\hline $201-300$ & 2 & 0 & $\mathbf{2}$ \\
\hline$>300$ & 3 & 5 & $\mathbf{8}$ \\
\hline Totaal & $\mathbf{1 1}$ & 7 & $\mathbf{1 8}$ \\
\hline
\end{tabular}

In vijf van de zeven zaken (71.4\%) waarbij een hoeveelheid van honderd planten of minder is gevonden heeft de belanghebbende gelijk gekregen. In het geval van meer dan driehonderd planten is dat in slechts drie van de acht zaken (37.5\%). Dit is echter geen significant verschil $(p=0,4)$.

Uit tabel 7 blijkt dat in vijftien van de twintig zaken waarin harddrugs zijn aangetroffen, is achterhaald hoeveel gram harddrugs zijn aangetroffen. ${ }^{34}$ Het totale aantal gram dat gevonden is in deze zaken is ruim 32 kilogram harddrugs. Gemiddeld per zaak is dit ruim twee kilogram harddrugs. De mediaan is iets meer dan negen kilogram.

Tabel 7 Hoeveelheid harddrugs in gram per zaak

\begin{tabular}{|l|l|l|l|}
\hline $\begin{array}{l}\text { Hoeveelheid } \\
\text { in gram }\end{array}$ & $\begin{array}{l}\text { Belanghebbende } \\
\text { gelijk }\end{array}$ & $\begin{array}{l}\text { Belanghebbende } \\
\text { ongelijk }\end{array}$ & $\begin{array}{l}\text { Totaal } \\
\text { aantal } \\
\text { zaken }\end{array}$ \\
\hline o-100 & 4 & 4 & $\mathbf{8}$ \\
\hline $101-200$ & o & 2 & $\mathbf{2}$ \\
\hline $201-300$ & 1 & 0 & $\mathbf{1}$ \\
\hline$>300$ & o & 4 & $\mathbf{4}$ \\
\hline Totaal & $\mathbf{5}$ & $\mathbf{1 0}$ & $\mathbf{1 5}$ \\
\hline
\end{tabular}

Tabel 7 laat zien dat in acht van deze vijftien zaken (53.3\%) een hoeveelheid van hoogstens honderd gram is gevonden, waarbij $2 . .84$ gram de kleinste aangetroffen hoeveelheid is. In de helft van de zaken vecht de belanghebbende de sluiting met succes aan. In zeven van de vijftien zaken (46.7\%) is een hoeveelheid aangetroffen van meer dan honderd gram harddrugs, waarbij 18.5 kilogram de grootste gevonden hoeveelheid harddrugs is. In slechts een van de zeven zaken (14.3\%) krijgt de belanghebbende gelijk. Van een significant verschil in uitkomst tussen zaken over minder en meer dan honderd gram harddrugs is geen sprake $(\mathrm{p}=0.14)$.

\subsection{Soort bezwaren}

In tabel 8 zijn de meest genoemde bezwaren opgesomd. In vijf uitspraken komen geen inhoudelijk bezwaren van de belanghebbende aan de orde. In deze zaken constateert de rechter zelfstandig gebreken van het besluit of liep het verzoek stuk op het vereiste van 'spoedeisend belang' in de voorlopigevoorzieningenprocedure. 
Tabel 8 Bezwaren van de belanghebbende

\begin{tabular}{|l|l|}
\hline Soort bezwaar & $\begin{array}{l}\text { Aantal keren } \\
\text { opgeworpen }\end{array}$ \\
\hline Onevenredige gevolgen & 46 \\
\hline Betwisten bevoegdheid burgemeester & 30 \\
\hline Recht op privéleven/art. 8 EVRM & 23 \\
\hline Betwist wetenschap overtreding & 22 \\
\hline $\begin{array}{l}\text { Betwisten } \\
\text { overtreding/handelshoeveelheid }\end{array}$ & 17 \\
\hline Bestraffende sanctie & 9 \\
\hline Besluit onvoldoende gemotiveerd & 2 \\
\hline Geen bezwaar geconstateerd & 5 \\
\hline
\end{tabular}

Uit tabel 8 kan worden opgemaakt dat de belanghebbende in 46 (70.8\%) zaken aanvoert dat de gevolgen van de sluiting onevenredig zijn. Dit heeft veelal te maken met de persoonlijke omstandigheden van de belanghebbende, zoals de aanwezigheid van (jonge) kinderen, dakloosheid als gevolg van de woningsluiting of de gevolgen van de sluiting voor zijn financiën of gezondheid. Onevenredige gevolgen kunnen ook te maken hebben met de duur van de sluiting. Daarnaast wordt veelal aangegeven dat eerst had moeten worden gewaarschuwd en dat de sluiting op zichzelf onredelijk wordt bevonden. In dat geval wordt sluiting voornamelijk als een te zwaar middel gezien.

In 23 zaken (35.4\%) beroept de belanghebbende zich expliciet op het recht op respect voor zijn privéleven en woning uit artikel 8 EVRM. De belanghebbende wijst in deze zaken veelal op de uit de artikel voortvloeiende verplichting van de burgemeester om bij het nemen van zijn besluit rekening te houden met het proportionaliteits- en subsidiariteitsbeginsel. De duur van de sluiting moet opwegen tegen de ernst van de overtreding en daarnaast moeten geen minder vergaande middelen voor handen zijn die hetzelfde effect teweegbrengen. Hierbij kan gedacht worden aan een waarschuwing of een last onder dwangsom. In dertig zaken (46.2\%) voert de belanghebbende aan dat de burgemeester niet bevoegd was om over te gaan tot sluiting van de woning. De belanghebbende beweert dan veelal dat niet is voldaan aan de toepassingsvoorwaarden zoals die staan omschreven in artikel 13b Opiumwet. In het kader van dit verweer wordt voornamelijk aangevoerd dat de burgemeester niet bevoegd is om op te treden tegen hennepkwekerijen of dat enkele aanwezigheid van een handelshoeveelheid niet voldoende is voor sluiting van de woning In zeventien zaken (26.2\%) betwist de belanghebbende dat de Opiumwet is overtreden. Hij betoogt dan dat er daarom geen reden is voor de sluiting. De belanghebbende voert bijvoorbeeld aan dat in de woning geen handelshoeveelheid drugs aanwezig is of dat de aangetroffen drugs voor eigen gebruik zijn. 
In 22 zaken (33.8\%) betwist de belanghebbende de overtreding niet, maar stelt wel dat hij geen wetenschap van de overtreding had. In zes van de tien zaken (60.0\%) waarin de belanghebbende 'slechts' de eigenaar is van de woning, voert de belanghebbende dit bezwaar aan. Veelal gaat het dan om een belanghebbende die de woning verhuurde en geen weet had van de situatie in de verhuurde woning. Indien de belanghebbende woonachtig is in de woning - dus alleen bewoner of eigenaar-bewoner is - wordt de wetenschap van de drugshandel in zestien zaken van de 55 (29.1\%) betwist. In dit soort zaken gaat het bijvoorbeeld om een medebewoner die in bezwaar ging tegen de sluiting omdat hij geen weet had van de situatie. $\mathrm{Er}$ is echter geen sprake van een significant verschil in opwerpen van dit bezwaar door belanghebbenden die enkel eigenaar zijn en belanghebbenden die eigenaar-bewoner zijn ( $p=0.06)$.

Er zijn nog twee andere soorten bezwaren die belanghebbenden aanvoeren. Zo stelt de belanghebbende in negen zaken (13.9\%) dat de sluiting van de woning een punitief effect heeft en moet worden aangemerkt als bestraffende sanctie in plaats van een herstelsanctie. Ten slotte voert de belanghebbende in slechts twee zaken expliciet aan dat het besluit van de burgemeester onvoldoende is gemotiveerd.

\subsection{Soort uitspraken}

Vervolgens is het interessant om te onderzoeken of de belanghebbende succesvol is bij het aanvechten van het besluit van de burgemeester. In 29 zaken (44.6\%) geeft de (voorzieningen)rechter de belanghebbende gelijk. Tabel 9 geeft aan wat de reden is voor de toewijzing van het verzoek voor het treffen van een voorlopige voorziening of de gegrondverklaring van het beroep van belanghebbende.

Tabel 9 Reden voor gegrondverklaring van beroep/toewijzing van verzoek voorlopige voorziening

\begin{tabular}{|l|l|l|l|}
\hline $\begin{array}{l}\text { Reden voor } \\
\text { toewijzing }\end{array}$ & $\begin{array}{l}\text { Reden is } \\
\text { een } \\
\text { grondslag }\end{array}$ & $\begin{array}{l}\text { Reden is } \\
\text { enige } \\
\text { grondslag }\end{array}$ & $\begin{array}{l}\text { Totaal aantal keren reden } \\
\text { voor } \\
\text { gegrondverklaring/toewijzing }\end{array}$ \\
\hline $\begin{array}{l}\text { Besluit niet } \\
\text { deugdelijk } \\
\text { gemotiveerd }\end{array}$ & 6 & 8 & $\mathbf{1 4}$ \\
\hline $\begin{array}{l}\text { Er had } \\
\text { moeten } \\
\text { volstaan met } \\
\text { waarschuwing }\end{array}$ & 3 & 3 & $\mathbf{6}$ \\
\hline $\begin{array}{l}\text { Geen sprake } \\
\text { van } \\
\text { overtreding }\end{array}$ & $\mathbf{1}$ & 4 & $\mathbf{5}$ \\
\hline $\begin{array}{l}\text { Sluiting is in } \\
\text { strijd met art. } \\
\text { 8 EVRM }\end{array}$ & 5 & $\mathbf{0}$ & $\mathbf{5}$ \\
\hline
\end{tabular}




\begin{tabular}{|l|l|l|l|}
\hline $\begin{array}{l}\text { Onevenredige } \\
\text { gevolgen }\end{array}$ & 4 & o & $\mathbf{4}$ \\
\hline $\begin{array}{l}\text { Geen sprake } \\
\text { van overlast }\end{array}$ & 3 & o & $\mathbf{3}$ \\
\hline $\begin{array}{l}\text { Andere } \\
\text { redenen }\end{array}$ & - & - & $\mathbf{4}$ \\
\hline
\end{tabular}

Uit de tabel blijkt dat in bijna de helft van deze 29 zaken (48.3\%) de ondeugdelijke motivering van het besluit voor de rechter een belangrijke rol speelt in de gegrondverklaring van het beroep, dan wel in de toewijzing van de voorlopige voorziening. In acht zaken is de ondeugdelijke motivering van het besluit van de burgemeester de enige reden voor de rechter om de belanghebbende in het gelijk te stellen. In zes zaken was dit een van meerdere redenen voor de beslissing van de rechter.

In zes van de 29 zaken (20.7\%) geeft de rechter aan dat had moeten worden volstaan met een waarschuwing. In twee van deze zes zaken kan het beleid van de burgemeester de toets in rechte niet doorstaan. In het eerste geval gaat het om beleid waarin het 'one strike and you're out'principe wordt gehanteerd. De voorzieningenrechter oordeelt in dit geval dat een dergelijk principe ter zake van softdrugs onredelijk is en dat eerst moet worden gewaarschuwd. $\mathbf{3 5}$ In de tweede zaak acht de rechter het beleid onrechtmatig omdat het beleid zou stellen dat de enkele aanwezigheid van een handelshoeveelheid softdrugs in een woning voldoende is om direct over te gaan tot sluiting van de woning. ${ }^{\mathbf{3 6}}$ In vijf van de 29 zaken (17.2\%) is de rechter van oordeel dat er geen sprake was van een overtreding van de Opiumwet. In drie zaken (10.3\%) heeft de rechter meegenomen dat er geen sprake was van overlast. In het merendeel van de zaken gaat de aandacht van de rechter dus uit naar de precieze toepassing van de sluitingsbevoegdheid en de gevolgen daarvan en niet zozeer naar de overtreding van de Opiumwet en de gevolgen daarvan. Uit tabel 9 blijkt eveneens dat in slechts acht zaken (27.6\%) expliciet is verwezen naar de overtreding als reden voor gegrondverklaring/toewijzing. In vijf van de 29 zaken (17.2\%) vormt strijdigheid met artikel 8 EVRM een grondslag voor de gegrondverklaring dan wel toewijzing van de voorlopige voorziening. In vier van de 29 zaken (13.8\%) heeft de rechter expliciet aangegeven dat de gevolgen voor belanghebbende onevenredig zijn. Er zit logischerwijs overlap tussen deze zaken: in drie zaken vormt zowel een schending van artikel 8 EVRM als de onevenredige gevolgen van de sluiting een grondslag voor de gegrondverklaring dan wel toewijzing van de voorlopige voorziening. Het bezwaar van de onevenredige gevolgen wordt - zoals uit tabel 8 blijkt - het meest aangevoerd: in iets meer dan 70\% van alle zaken. In vijftien van de 29 zaken waarin de belanghebbende gelijk krijgt, wijst de belanghebbende op onevenredige gevolgen. In bijna de helft van die vijftien zaken gaat de rechter expliciet in op de argumenten van de burger. De rechter noemt de gevolgen dus niet altijd als grondslag voor zijn uitspraak, maar neemt ze wel vaak mee in zijn beoordeling. In vier zaken wordt het beroep gegrond verklaard of het verzoek op voorlopige voorziening toegewezen op andere gronden dan vermeld in de tabel. In een van deze zaken acht de rechter de burgemeester onbevoegd, 
omdat er slechts sprake is van enkele aanwezigheid van een handelshoeveelheid drugs zonder indicatie van verkoop vanuit de woning. ${ }^{37}$ Dit is de enige grond die de rechtbank aanvoert om het beroep gegrond te verklaren. In deze uitspraak gaat het om het idee dat sprake moet zijn van bijzondere omstandigheden die een sluiting rechtvaardigen. In twee andere zaken is de burgemeester eveneens onbevoegd verklaard, omdat de bevoegdheid van burgemeester, volgens de rechter, niet bedoeld is om hennepkwekerijen aan te pakken. ${ }^{\mathbf{3}}$ In de vierde zaak beslist de rechter dat de burgemeester onvoldoende aannemelijk heeft gemaakt dat sprake is van een zodanig spoedeisende situatie dat mag worden afgezien van de hoorplicht uit artikel 4:8 Awb. ${ }^{39}$

In 36 zaken komt de rechter tot de conclusie dat de belanghebbende de sluiting tevergeefs aanvecht. Tabel 10 laat zien dat er hoofdzakelijk zes redenen worden aangevoerd door de rechter om het beroep ongegrond te verklaren/verzoek tot voorlopige voorziening af te wijzen.

Tabel 10 Reden voor ongegrondverklaring van beroep/afwijzing van verzoek voorlopige voorziening

\begin{tabular}{|l|l|l|l|}
\hline $\begin{array}{l}\text { Reden voor } \\
\text { afwijzing }\end{array}$ & $\begin{array}{l}\text { Reden is } \\
\text { een } \\
\text { grondslag }\end{array}$ & $\begin{array}{l}\text { Reden is } \\
\text { enige } \\
\text { grondslag }\end{array}$ & $\begin{array}{l}\text { Totaal aantal keren reden voor } \\
\text { ongegrondverklaring/afwijzing }\end{array}$ \\
\hline $\begin{array}{l}\text { Belangen van de } \\
\text { belanghebbende } \\
\text { niet onevenredig } \\
\text { geschaad }\end{array}$ & 27 & 2 & $\mathbf{2 9}$ \\
\hline $\begin{array}{l}\text { Handelshoeveelheid } \\
\text { aanwezig }\end{array}$ & 25 & 3 & $\mathbf{2 8}$ \\
\hline $\begin{array}{l}\text { Sprake van } \\
\text { hennepkwekerij }\end{array}$ & 8 & 0 & $\mathbf{8}$ \\
\hline $\begin{array}{l}\text { Sprake van een } \\
\text { ernstig geval }\end{array}$ & 7 & 0 & 7 \\
\hline Sprake van overlast & 2 & 0 & $\mathbf{2}$ \\
\hline $\begin{array}{l}\text { Waarschuwing is } \\
\text { niet verplicht }\end{array}$ & 2 & 0 & $\mathbf{2}$ \\
\hline Andere redenen & - & - & $\mathbf{3}$ \\
\hline
\end{tabular}

Twee redenen worden verreweg het meest genoemd. Ten eerste concludeert de rechter in 29 van de 36 zaken (80.6\%) dat de belangen van de belanghebbende niet onevenredig zijn geschaad. Veelal weegt de rechter de belangen van de belanghebbende expliciet af tegen het algemeen belang, maar laat hij het algemeen belang in de meeste zaken prevaleren. Indien het bezwaar voornamelijk gericht is op de duur van de sluiting geeft de rechter doorgaans aan dat de duur van de sluiting niet onredelijk is omdat de gestelde termijn ervoor zorgt dat de loop naar de woning en de bekendheid hiervan in kringen van drugsgebruikers wordt doorbroken. ${ }^{40}$ 
Ten tweede benadrukt de rechter in 28 van de 36 zaken (77.8\%) de aanwezigheid van een handelshoeveelheid drugs in de woning. In drie van deze zaken doet de rechter de zaak zelfs af met de enkele verwijzing van de aanwezigheid van een handelshoeveelheid drugs in de woning. In acht van de 36 zaken (22.2\%) acht de rechter het van groot belang dat in de woning een hennepkwekerij is aangetroffen.

In zeven van alle 65 geanalyseerde zaken wordt door de burgemeester aangeven dat sprake is van overlast. In slechts twee van de 36 zaken (5.6\%) noemt de rechter dit expliciet als grondslag van zijn beslissing. Daarnaast geeft de rechter in twee zaken aan dat de burgemeester niet verplicht is om een waarschuwing te geven alvorens hij de bevoegdheid uit artikel 13b Opiumwet kan toepassen.

In drie zaken wijst de rechter het verzoek op voorlopige voorziening af op andere gronden dan vermeld in tabel 10. In twee zaken heeft belanghebbende niet het vereiste spoedeisende belang aangetoond (art. 8:81 Awb) en komt hij daarom niet in aanmerking voor toewijzing van de voorlopige voorziening. ${ }^{41}$ In één zaak is het verzoek tot voorlopige voorziening afgewezen doordat er geen omstandigheden waren op grond waarvan de burgemeester moest afwijken van zijn beleid en doordat de belangenafweging in voldoende mate heeft plaatsgevonden. ${ }^{42}$

\section{Discussie en conclusie}

De bovenstaande analyse van beleidsstukken en jurisprudentie resulteert in een aantal conclusies. Allereerst lijkt er sprake van een stijgende lijn van het aantal woningsluitingen. In verschillende gemeenten wordt gemeld dat sprake is van een stijgende lijn in het aantal sluitingen. De bevoegdheid lijkt bovendien veelvuldig gebruikt te worden als basis voor bestuurlijke waarschuwingen die door burgemeesters worden gegeven. Hoe vaak artikel 13b Opiumwet exact wordt toegepast valt echter niet met zekerheid te zeggen. Zo maken de cijfers die bekend zijn over de toepassing veelal geen onderscheid tussen lokalen en woningen en zijn slechts data over een klein aantal gemeenten en provincies bekend. Hierdoor kan geen helder beeld worden geschetst van het totale toepassingsbereik in Nederland. Op basis van onze analyse schatten wij dat de bestuursdwangbevoegdheid van november 2007 tot januari 2015 zeker honderd keer is toegepast, maar achten het gezien de geanalyseerde data niet aannemelijk dat de bevoegdheid meer dan vierhonderd keer door burgemeesters is gebruikt. Vervolgens is het de vraag hoe vaak de toepassing van artikel $13 \mathrm{~b}$ Opiumwet tot een voorlopigevoorzieningenprocedure of beroepsprocedure bij de rechter heeft geleid. Wederom ontbreken hier kwantitatieve data en kunnen wij geen exact aantal zaken achterhalen. Om deze lacune enigszins te vullen, hebben wij alle op www.rechtspraak.nl gepubliceerde jurisprudentie systematisch en zorgvuldig geanalyseerd. Uiteindelijk zijn 65 uitspraken betrokken in onze analyse. Deze relatief kleine dataset maakt dat wij voorzichtig moeten zijn met het trekken van conclusies, omdat niet duidelijk is hoe groot de populatie is van zaken omtrent artikel $13 \mathrm{~b}$ Opiumwet die tot een voorlopigevoorzieningenprocedure of beroepsprocedure leiden. Om deze reden kunnen vraagtekens worden gezet bij de representativiteit van onze database. Logischerwijs is het totale aantal rechtszaken niet groter dan het aantal woningsluitingen op grond 
van artikel 13b Opiumwet tussen november 2007 en januari 2015. De geanalyseerde gemeentelijke documenten tonen bovendien aan dat niet elke woningsluiting leidt tot bezwaar, een voorlopigevoorzieningenprocedure en/of een beroepsprocedure. Nu onze schatting is dat de bevoegdheid tussen de honderd en vierhonderd keer is toegepast, menen wij dat voorzichtige conclusies op basis van een analyse van 65 gepubliceerde uitspraken gerechtvaardigd is. Ondanks de evident zwakke punten geeft het onderzoek een eerste cijfermatig inzicht in de problematiek rond gerechtelijke procedures van woningsluitingen op grond van artikel $13 \mathrm{~b}$ Opiumwet.

Aan de hand van de statistische analyse vallen enkele conclusies te trekken over de kenmerken van zaken over de toepassing van artikel 13b Opiumwet die bij de rechter terechtkomen. In bijna de helft van de zaken is de belanghebbende de bewoner en tevens eigenaar van de gesloten woning. De woning is in bijna drie kwart van de zaken gesloten wegens het aantreffen van een handelshoeveelheid drugs. Ook is hennepteelt een belangrijke reden voor sluiting van de woning: in bijna $40 \%$ van de zaken wordt de woning (mede) om die reden gesloten. Actieve drugshandel en drugslaboratoria vormen in een kleine groep zaken de reden voor de sluiting. De meeste zaken gaan om softdrugs: in bijna twee derde van de geanalyseerde zaken is handel in en/of aanwezigheid van een handelshoeveelheid softdrugs een reden voor de sluiting van de woning. In meerderheid van de zaken is de aangetroffen handelshoeveelheid softdrugs hoogstens tien kilogram of zijn minder dan driehonderd hennepplanten aangetroffen.

Uit bijna drie kwart van de zaken die tot een gerechtelijke procedure leiden blijkt dat de burgemeester een handhavingsbeleid heeft. Het opstellen van beleid is conform de wens van de wetgever. Tijdens de parlementaire behandeling is de noodzaak voor het opstellen van beleidsregels herhaaldelijk benadrukt. Het is volgens de wetgever niet de bedoeling dat bij een eerste overtreding van de Opiumwet meteen tot sluiting wordt overgegaan. ${ }^{43} \mathrm{Er}$ is gepleit voor een getrapte sanctionering. De toenmalige regering meent dat het wenselijk is dat gemeenten een stappenplan hanteren, maar zij wil gemeenten daar niet toe verplichten. ${ }^{44}$ Hoewel burgemeesters conform de wens van de wetgever beleid opstellen, blijkt van gefaseerd optreden in de geanalyseerde 65 zaken niet veel. Doorgaans voeren burgemeesters in de geanalyseerde zaken een zogenaamd 'one strike and you're out'-beleid bij de toepassing van artikel 13b Opiumwet. Het feit dat in slechts één zaak in onze database voorafgaand is gewaarschuwd staat op gespannen voet met de bedoeling van de wetgever. Deze bevinding contrasteert bovendien met de cijfers van de Regionale Informatie en Expertise Centra waaruit blijkt dat artikel 13b Opiumwet vaak wordt gebruikt als basis voor een waarschuwing. 45 Dat in de zaken uit onze dataset nauwelijks is gewaarschuwd heeft meerdere mogelijke verklaringen: het kan een indicatie zijn dat de 65 uitspraken voornamelijk afkomstig zijn uit gemeenten die weinig worden geconfronteerd met de toepassing van de Wet Damocles. Hierdoor gaan zij onjuist of overhaast te werk door direct over te gaan tot sluiting van de woning. Dit kan tevens verklaren waarom bijvoorbeeld de vele sluitingen in Tilburg tussen 2007 en 2015 slechts tot twee gerechtelijke procedures hebben geleid, terwijl uit de cijfers blijkt dat Noord-Brabant na Limburg de provincie is met de 
meeste drugscriminaliteit. Dat slechts twee zaken bij de rechter zijn beland kan een indicatie zijn om aan te nemen dat bijvoorbeeld de burgemeester van Tilburg over een degelijk handhavingsbeleid beschikt en ervaren is in de toepassing daarvan. Een andere mogelijke verklaring is dat de 65 uitspraken vooral 'zwaardere' zaken zijn. In dit soort zaken wordt een relatief grote handelshoeveelheid drugs aangetroffen, waarna de burgemeester direct overgaat tot sluiting van de woning. Het voeren van een dergelijk 'one strike and you're out'-beleid, staat weliswaar op gespannen voet met de bedoeling van de wetgever, maar wordt sinds 2015 in juridische zin niet meer als problematisch beschouwd. De Afdeling heeft in 2015 benadrukt dat het van belang is dat eerst wordt gewaarschuwd voordat wordt overgegaan tot sluiting, maar dat daarvan kan worden afgeweken als sprake is van een ernstig geval. Er is echter al snel sprake van een ernstig geval. Zo acht de Afdeling een waarschuwing bijvoorbeeld niet nodig bij een handelshoeveelheid van meer dan twintig hennepplanten. ${ }^{\mathbf{4}}$

De analyse leert ons verder iets over de omstandigheden waaronder de belanghebbende het sluitingsbesluit met succes aanvecht. In bijna de helft van de geanalyseerde zaken is de belanghebbende succesvol. De soort belanghebbende lijkt echter niet van invloed te zijn op de uitkomst in een gerechtelijke procedure. Dit in tegenstelling tot de soort drugs: deze lijkt wel van invloed te zijn op de beslissing van de rechter. In bijna twee derde van de zaken is softdrugs aangetroffen. In de zaken waar alleen softdrugs is aangetroffen vecht de belanghebbende het besluit in de helft van de zaken met succes aan. In de zaken waarin harddrugs is aangetroffen vecht de belanghebbende in iets meer dan 20\% van de gevallen het besluit met succes aan. Onze analyse trof echter net geen statistisch verschil in uitkomst tussen zaken over hard- en softdrugs. Desondanks laat het grote verschil wel zien dat burgemeesters en rechters mogelijk geneigd zijn om strenger te oordelen in geval van harddrugs dan in geval van softdrugs. Dat de aanwezigheid van een handelshoeveelheid harddrugs als een zwaardere overtreding wordt gezien dan de aanwezigheid van een handelshoeveelheid softdrugs blijkt ook uit het aanwijzingsbesluit waarin de grens van een handelshoeveelheid harddrugs is gelegd op een halve gram en bij softdrugs pas op vijf gram. ${ }^{47}$

Daarnaast werd ook geen significant verschil gevonden in uitkomst tussen zaken waarin een kleine hoeveelheid drugs werd gevonden en zaken waarin een grote hoeveelheid drugs aangetroffen werd. In het geval een hoeveelheid hennepplanten is gevonden bestaat er geen significant verschil in uitkomst tussen zaken waarin relatief weinig planten zijn aangetroffen en zaken waarin relatief veel planten zijn gevonden. Hetzelfde geldt voor de zaken waarin een handelshoeveelheid soft- en/of harddrugs in gram is aangetroffen. De grote verschillen in percentages lijken te indiceren dat een grote hoeveelheid drugs minder vaak tot succes voor de belanghebbende leidt, maar er kan wederom niet gesproken worden van een significant verschil.

Belanghebbenden geven in bijna drie kwart van de zaken aan dat de gevolgen van de sluiting onredelijk zijn. Zij wijzen doorgaans op de duur van de sluiting, het feit dat niet van tevoren is gewaarschuwd en dat onvoldoende rekening is gehouden met persoonlijke omstandigheden. In $43 \%$ van de zaken waarin de belanghebbende gelijk krijgt, voert hij aan dat 
de gevolgen onevenredig zijn. In slechts vier zaken heeft de rechter echter expliciet aangegeven dat de gevolgen voor belanghebbende daadwerkelijk onevenredig zijn. In bijna de helft van de zaken waarin belanghebbende gelijk krijgt en een beroep doet op de onevenredige gevolgen, gaat de rechter expliciet in op de argumenten van de burger. Ondanks het feit dat de rechter de gevolgen niet altijd als grondslag noemt voor zijn uitspraak worden ze dus wel vaak meegenomen in de beoordeling. Dat de rechter de gevolgen van de sluiting vaak meeneemt in zijn beoordeling blijkt ook uit het feit dat de rechter in meer dan $80 \%$ van de zaken waarin de belanghebbende geen gelijk krijgt, expliciet stelt dat de belangen van de burger niet onevenredig zijn geschaad.

Een ander bezwaar dat relatief succesvol lijkt te zijn, betreft het wijzen op de ondeugdelijke motivering. Wat opvalt is dat in bijna de helft van de zaken (14 van de 29) waarin de belanghebbende het sluitingsbesluit met succes aanvecht, door de rechter is aangevoerd dat het besluit ondeugdelijk is gemotiveerd. Dit bezwaar werpt de burger echter in slechts twee zaken expliciet op. Dit laat zien dat de rechter het besluit doorgaans ambtshalve controleert op deugdelijke motivering. Naast het bezwaar dat de gevolgen onevenredig zijn, is er nog een ander bezwaar dat geregeld wordt aangevoerd. In bijna de helft van de zaken voert belanghebbende aan dat de burgemeester niet bevoegd is tot sluiting van de woning. Hieronder wordt veelal verstaan dat de burgemeester niet bevoegd is om op te treden tegen hennepkwekerijen of dat de enkele aanwezigheid van een handelshoeveelheid niet voldoende is voor sluiting van de woning. Uit onze analyse volgt dat deze bewaren redelijk succesvol zijn. In eerste instantie valt hennepteelt namelijk niet onder het toepassingsbereik van artikel 13b Opiumwet. De meerderheid van de Tweede Kamer vindt namelijk dat artikel 17 Woningwet bedoeld is om woningen te sluiten in geval van hennepteelt. ${ }^{48}$ Met deze lijn is echter gebroken. De Afdeling bepaalt in 2013 dat indien een hoeveelheid hennepplanten wordt aangetroffen van meer dan vijf planten, het aannemelijk is dat de hennepplanten bestemd zijn voor verkoop, aflevering of verstrekking vanuit de woning. Dat het om een hennepkwekerij gaat betekent niet dat de burgemeester niet bevoegd is om artikel 13b Opiumwet toe te passen. ${ }^{49}$ Daarnaast stelt de Afdeling in 2015 dat voor toepassing van artikel 13b Opiumwet niet vereist is dat daadwerkelijk drugs in de woning zijn verhandeld. Uit het woord 'daartoe' in artikel 13b Opiumwet volgt dat de enkele aanwezigheid van een handelshoeveelheid drugs in de woning voldoende is voor sluiting. ${ }^{\mathbf{5}}$ Zowel hennepkwekerijen als de enkele aanwezigheid van een handelshoeveelheid drugs zijn dus tegenwoordig op zichzelf staande redenen voor de sluiting van een woning. Gezien deze strenge lijn in de Afdelingsjurisprudentie verwachten wij dat in het vervolg het bezwaar dat de burgemeester niet bevoegd is om een woning te sluiten in geval van een hennepplantage of een handelshoeveelheid drugs, niet langer succesvol zal zijn. Hetzelfde geldt voor het aanvoeren dat niet van tevoren is gewaarschuwd. In zes uitspraken oordeelt de rechter dat had moeten worden volstaan met een waarschuwing. Er blijkt echter onduidelijkheid te bestaan over de noodzaak tot het geven van een waarschuwing. In twee andere uitspraken beslist de rechter namelijk dat een waarschuwing juist niet verplicht is. Vanaf 2015 lijken belanghebbenden zich echter niet meer met succes te 
kunnen beroepen op een eventuele waarschuwingsplicht: de Afdeling oordeelt in een recente uitspraak dat waarschuwen in beginsel niet verplicht is indien een grote handelshoeveelheid drugs wordt aangetroffen in een woning. ${ }^{\mathbf{5 1}}$

Bezwaren die niet of nauwelijks succesvol blijken zijn het betwisten van de wetenschap van de overtreding, het bezwaar dat het gaat om een punitieve sanctie en het bezwaar dat sprake is van een inbreuk op artikel 8 EVRM. Vooral dat laatste wekt verbazing. Het aanvoeren van artikel 8 EVRM is weliswaar enigszins succesvol in combinatie met het wijzen op onevenredige gevolgen, maar op zichzelf vormt het amper een grondslag voor het gelijk van de burger. De Raad van State pleitte er tijdens de parlementaire behandeling voor om de bevoegdheid van artikel 13b Opiumwet met meer waarborgen te omkleden met het oog op artikel 8 EVRM. Dit is destijds niet overgenomen door de regering. Dit verklaart wellicht waarom een expliciet beroep door de belanghebbende op artikel 8 EVRM doorgaans niet succesvol is. Rechters gaan er wellicht van uit dat de wetgever tijdens de behandeling van het wetsvoorstel aangaande artikel 13b Opiumwet voldoende rekening heeft gehouden met de voorwaarden uit artikel 8 EVRM. Bovendien letten rechters er doorgaans wel op dat in het handhavingsbeleid van burgemeesters een minder vergaande maatregel staat opgenomen dan sluiting.

Wij verwachten dat de bezwaren van burgers over de waarschuwingsplicht en de bevoegdheid van de burgemeester om woningen te sluiten in geval van een handelshoeveelheid drugs of hennepkwekerijen in het vervolg niet meer succesvol zullen zijn. De enige bezwaren die dan nog succesvol lijken, zijn het bezwaar tegen de ondeugdelijke motivering van het sluitingsbesluit en de onevenredige gevolgen in combinatie met artikel 8 EVRM.

De bevindingen uit deze eerste analyse van de toepassing artikel $13 \mathrm{~b}$ Opiumwet zorgen voor een nieuw begrip van de gerechtelijke procedures en juridische redeneringen in zaken over drugshandel en hennepteelt. Doordat dit een relatief klein onderzoek is, verdient het aanbeveling om nader empirisch onderzoek te doen naar de sluitingsbesluiten en de beslissingen op bezwaar om een goed beeld te krijgen van de toepassing van artikel 13b Opiumwet. Eveneens kunnen niet op www.rechtspraak.nl gepubliceerde uitspraken worden betrokken bij verdere analyses. Door verder onderzoek te doen op dit gebied kan zowel nuttige informatie voor burgemeesters als voor burgers worden verkregen. Voor burgemeesters kan het bijvoorbeeld interessant zijn om te bezien waar de sluiting van woningen voornamelijk op wordt afgewezen en aan welke voorwaarde zij extra aandacht moeten besteden bij de besluitvorming. Voor burgers is het essentieel om te weten welke strategie het meest effectief is om gelijk te krijgen bij de rechter.

\section{Noten}

1 Zie A.C.M. Spapens, H.G. van de Bunt \& L. Rastovac, De wereld achter wietteelt, Den Haag: WODC 2007.

2 Zie P. Tops \& E. van der Torre, Wijkenaanpak en ondermijnende criminaliteit, Tilburg: Tilburg University/Politieacademie 2014, p. 12-15. 
3 Zie H.M.B. Breunese, J.G. Brouwer \& A.E. Schilder, Wapenen tegen drugsoverlast, Deventer: W.E.J. Tjeenk Willink 1996; W. Wouters, D.J. Korf \& B. Kroeske, Harde aanpak, hete zomer. Een onderzoek naar de ontmanteling van hennepkwekerijen in Nederland, Den Haag: WODC 2005; D.M.A. bij de Vaate, 'Wie hennep teelt, zal oogsten? Toereikendheid van de bestuursrechtelijke bevoegdheden ter ontmoediging van de illegale hennepteelt', Gst. 2010/7340, p. 392-398; W.D. Lok, Hennepteelt en huurrecht, Tilburg: Celsus Juridische uitgeverij 2010; M. Schuilenburg \& W. van der Wagen, 'Samenwerkingen in de criminaliteitsbestrijding', Tijdschrift voor Veiligheid 2011-1, p. 10-25; M. Schuilenberg, Orde in veiligheid. Een dynamisch perspectief, Den Haag: Boom Lemma uitgevers 2012; M. Vols, Woonoverlast en het recht op privéleven, Den Haag: Boom Juridische uitgevers 2013.

4 Zie H.M.B. Breunese, J.G. Brouwer \& A.E. Schilder, 'Damocles en de mythe van de uitputtende Opiumwet', NJB 1997/33, p. 1541-1546; H.P.J.A.M. Hennekens, Openbare-orderecht, Deventer: Kluwer 2013, p. 54-64.

5 Zie Kamerstukken II 2005/o6, 30515, 3, p. 1-8; M.A.D.W. de Jong, 'De burgemeester als misdaadbestrijder: reddingsboei of dwaallicht', in: L.J.J. Rogier \& M.A.D.W. de Jong (red.), Bestuursrechtelijke aanpak van criminaliteit en terrorisme, Den Haag: Boom Juridische uitgevers 2007, p. 91-97.

6 Dit geldt volgens het tweede lid van art. 13b Opiumwet niet indien de woningen of erven gebruikt worden ter uitoefening van de artsenijbereidkunst, de geneeskunst, de tandheelkunst of de diergeneeskunde door onderscheidenlijk apothekers, artsen, tandartsen of dierenartsen.

7 Zie J.G. Brouwer \& A.E. Schilder, 'Woonoverlast en de persoonlijke levenssfeer: naar een balans tussen bescherming en beperking', NJCMBulletin 2011, p. 307-324; M. Vols, M. Kiehl \& J. Sidoli del Ceno, 'Human Rights and Protection against Eviction in Anti-social Behaviour Cases in the Netherlands and Germany', European Journal of Comparative Law and Governance 2015-2, p. 156-181.

8 Rb. Noord-Nederland 12 juni 2014, ECLI:NL:RBNNE:2014:2850.

9 ABRvS 21 januari 2015, ECLI:NL:RVS:2015:130.

10 Spapens, Van de Bunt \& Rastovac 2007, p. 9.

$11 \mathrm{M}$. Vols \& A. de Jonge, Overlast en verloedering. Evaluatie wetten Victoria en Victor, Den Haag: VROM-Inspectie 2009, p. 25.

12 T. Holtslag \& M. Vols, Woonoverlast: een analyse van de aanpak van woonoverlast en verloedering, Den Haag: VROM-Inspectie 2010. 
van Opiumwetfeiten in 2012 geregistreerd bij politie en Koninklijke

Marechaussee, Den Haag: WODC 2014, p. 25.

14 Kruize \& Gruter 2014, p. 55.

15 Kruize \& Gruter 2014, p. 49-50.

16 Kruize \& Gruter 2014, p. 51.

17 Flevoland heeft eveneens een hoge score. Dit komt vooral door een handhavingsactie op een festival waarbij bijna 250 keer bezit van harddrugs werd geconstateerd. Zie Kruize \& Gruter 2014, p. 28.

18 Vols \& De Jonge 2009, p. 25.

19 Zie RIEC Limburg, Jaarverslag RIEC 2012, februari 2013, p. 20. Zie ook J. Snippe, R. Nijkamp \& B. Bieleman, Onderzoek drugsbeleid Venlo 2012-2013, Groningen: Intraval 2013, p. 31-32.

20 Zie RIEC-LIEC, Jaarverslag RIEC-LIEC 2013, juli 2014.

21 Zie RIEC-LIEC 2014.

22 Zie Gemeente Rotterdam, Jaarverslag Bestuurlijke Handhaving 2013, Rotterdam: Bestuursdienst Rotterdam 2013, p. 9.

23 Zie Gemeente Rotterdam 2013, p. 9.

24 Zie Gemeente Tilburg, Damoclesbesluiten, maart 2015 (verkregen via de gemeente Tilburg).

25 Zie Gemeente Groningen, Evaluatie Damoclesbeleid, nr. 4834815, 11 februari 2015 .

26 Zie R.M. Lawless, J.K. Robbennolt \& T.S. Ulen, Empirical Methods in Law, Austin: Kluwer 2010, p. 165-183.

27 Zie Lawless, Robbennolt \& Ulen 2010, p. 227-261; M. Vols, P.G. Tassenaar \& J.P.A.M. Jacobs, 'Anti-social Behaviour and European Protection against Eviction', International Journal of Law in the Built Environment 2015-2, p. 148-161.

28 Veel uitspraken zijn gedaan voor 1 januari 2013, het moment dat de negentien rechtbanken zijn samengevoegd tot elf grotere arrondissementen.

29 In vier zaken moest de rechtbank zowel beoordelen of een voorlopige voorziening getroffen moet worden en of het beroep gegrond is. In het geval van deze zaken is enkel gekeken naar de uitkomst van de beroepsprocedure. 
30 Aanwijzing Opiumwet 2012 (vervallen); Aanwijzing Opiumwet 2015 (in werking sinds 1 maart 2015).

31 In drie zaken zijn zowel hennepplanten als softdrugs in gram aangetroffen. Deze zaken zijn zowel verwerkt in tabel 5 als 6. In twee uitspraken is de hoeveelheid softdrugs onbekend.

32 Deze data zijn niet geheel zuiver, omdat in sommige zaken wordt gesproken over het bruto gewicht (gewicht in planten of brokken) en in andere zaken over het netto gewicht (gewicht in wiet of hasjiesj). Daarnaast is er ook een zaak waarbij onder andere een hoeveelheid aan joints is gevonden; deze hoeveelheid kan niet in de bovenstaande cijfers worden meegenomen.

33 In deze zaak is een handelshoeveelheid harddrugs aangetroffen in combinatie met 4.7 gram hennep.

34 In twee zaken is de hoeveelheid harddrugs onbekend en in drie zaken is de hoeveelheid harddrugs niet onder te verdelen in gram doordat een hoeveelheid pillen is gevonden.

35 Rb. Limburg 4 februari 2013, ECLI:NL:RBLIM:2013:BZ2853.

36 Rb. Noord-Nederland 12 juni 2014, ECLI:NL:RBNNE:2014:2850.

37 Rb. Haarlem 4 december 2012, ECLI:NLRBHAA:2012:BY5942.

38 Rb. Haarlem 29 juni 2012, ECLI:NL:RBHAA:2012:BY5940; Rb. Haarlem 30 november 2012, ECLI:NL:RBHAA:2012:BY5387. Deze lijn is in 2011 doorbroken door de Rechtbank Roermond, die woningsluiting na het aantreffen van een hennepplantage toelaatbaar acht. Zie Rb. Roermond 3 mei 2011, ECLI:NL:RBROE:2011:BQ3816 m.nt. L.J.J. Rogier. Zie eveneens de discussie en conclusie (par. 5).

39 Rb. Maastricht 31 oktober 2012, ECLI:NL:RBMAA:2012:BY2863.

40 Zie bijv. Rb. 's-Gravenhage 26 juli 2012, ECLI:NL:RBSGR:2012:BX4316.

41 Rb. Maastricht 30 juli 2008, ECLI:NL:RBMAA:2008:BD8991; Rb. Maastricht 28 maart 2012, ECLI:NL:RBMAA:2012:BWO275.

42 Rb. Roermond 7 augustus 2009, ECLI:NL:RBROE:2009:BJ5137.

43 Kamerstukken II 2005/o6, 30515, 6.

44 Kamerstukken I 2006/o7, 30515, B \& C.

45 Zie RIEC-LIEC 2014.

46 ABRvS 21 januari 2015, ECLI:NL:RVS:2015:130. 
47 Aanwijzing Opiumwet 2015 (in werking sinds 1 maart 2015).

48 Zie Kamerstukken II 2006/o7, 30515, 14; Kamerstukken I 2006/07, 30515, B; Handelingen II 29 maart 2007, p. 55-3127, 55-3133, 55-3137, 553319, 55-3144; Handelingen II 3 april 2007, p. 56-3164.

49 Zie ABRvS 11 december 2013, ECLI:NL:RVS:2013:2362.

50 Zie ABRvS 21 januari 2015, ECLI:NL:RVS:2015:130.

51 ABRvS 21 januari 2015, ECLI:NL:RVS:2015:130.

(c) Boom Juridische uitgevers 